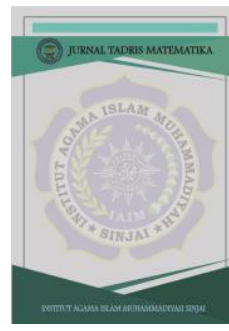

\title{
ANALISIS SOSIOMATEMATIKA BERBASIS KEARIFAN LOKAL DALAM PEMBELAJARAN PADA SISWA SDN 224 PALAE
}

\author{
Irmayanti $^{1}$, Nurul Islamiah ${ }^{2}$, Syarifuddin ${ }^{3}$ \\ ${ }^{1}$ Institut Agama Isilam Muhammadiyah Sinjai, Jl. Sultan Hasanuddin No. 20, Sinjai \\ ${ }^{2}$ Institut Agama Isilam Muhammadiyah Sinjai, Jl. Sultan Hasanuddin No. 20, Sinjai \\ ${ }^{3}$ Institut Agama Isilam Muhammadiyah Sinjai, Jl. Sultan Hasanuddin No. 20, Sinjai \\ E-mail: irmayanti91@gmail.com, Tlp:+6285242955389
}

\begin{abstract}
Abstrak
Tujuan penelitian ini adalah untuk mendeskripsikan pelaksanaan pembelajaran terkait sosiomatematika yang berbasis kearifan lokal di SDN 224 Palae. Indikator yang digunakan dalam penelitian ini adalah prosedur pemecahan masalah, prosedur pemecahan masalah yang dapat diterima, alternatif prosedur, perumusan prosedur yang lebih efektif. Jenis penelitian ini adalah penelitian deskriptif dengan pendekatan kualitatif. Sumber data penelitian ini adalah siswa kelas $V$ SDN 224 Palae. Adapun teknik pengumpulan data dalam penelitian ini adalah observasi, wawancara dan dokumentai. Instrumen yang digunakan adalah perangkat pembelajaran, lembar observasi, dan pedoman wawancara. Adapun analisis data yang digunakan adalah reduksi data, penyajian data, dan kesimpulan/verifikasi. Hasil penelitian menunjukkan bahwa pembelajaran matematika realistik dan pembelajaran kontekstual dapat mengasah kemampuan sosiomatematika siswa SDN 224 Palae Kelas $V$ yang berbasis pada kearifan lokal. Adapun indikator sosiomatematika yang dapat dicapai oleh siswa dengan pembelajaran matematika realistik adalah prosedur pemecahan masalah, alternatif prosedur sedangkan pada pembelajaran kontekstual adalah alternatif prosedur, perumusan prosedur yang lebih efektif, dan prosedur pemecahan masalah yang dapat diterima.
\end{abstract}

Kata Kunci: Pembelajaran, sosiomatematika, kearifan lokal

\begin{abstract}
Abstrak
The purpose of this research is to describe the implementation of sociomatematic related learning based on local wisdom at SDN 224 Palae. Indicators used in this study are problem-solving procedures, acceptable problem-solving procedures, alternative procedures, more effective formulation of procedures. This type of research is descriptive research with a qualitative approach. The data source of this research is grade V students at SDN 224 Palae. The data collection techniques in this study are observations and interviews. The instruments used are learning tools, observation sheets, and interview guidelines. The data analysis used is data reduction, data presentation, and conclusion/verification. The results showed that realistic mathematics learning and contextual learning can hone the sociomatematic skills of students of SDN 224 Palae Class V based on local wisdom. The sociomatematic indicators that can be achieved by students with realistic mathematics learning are problem-solving procedures, alternative procedures whereas in contextual learning are alternative procedures, more effective procedure formulation, and acceptable problemsolving procedures.
\end{abstract}

Keywords: Learning, sociomatematics, local wisdom 


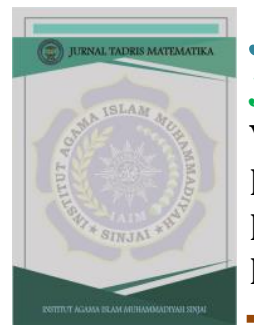

JTMT

Jurnal Tadris Matematika

Vol 1 No 22020

ISSN (print) : 2745-956X

ISSN (online) : 2745-9551

Homepage : http://iournal.iaimsinjai.ac.id/index.php/Jtm

\section{Pendahuluan}

Matematika merupakan salah satu mata pelajaran wajib pada jenjang sekolah dasar, sekolah menengah pertama dan sekolah menengah atas. Pembelajaran matematika membutuhkan interaksi antara guru dan siswa serta antarsiswa untuk menyelesaikan sebuah masalah matematika. Suatu proses belajar mengajar akan menjadi efektif jika para pembelajar saling mengkomunikasikan ide melalui interaksi sosial.

Pembelajaran matematika yang selama menjadi masalah diantaranya guru masih mendominasi dalam pembelajaran dengan kata lain guru masih menggunakan pembelajaran yang berpusat pada guru sehingga interaksi sosial yang terbentuk hanya dari peserta didik dengan guru. Interaksi antar peserta didik belum optimal karena proses pembelajaran matematika belum menggunakan pembelajaran berpusat pada peserta didik seperti yang diharapkan pada kurikulum 2013 saat ini. Sehingga untuk mengoptimalkan interaksi sosial terutama pada pembelajaran matematika, dibutuhkan sebuah model pembelajaran yang menekankan pada pola interaksi antar peserta didik.

Interaksi sosial yang terjadi dalam pembelajaran dipengaruhi faktor norma yang ada pada masyarakat setempat. Menurut (Wijaya, 2012), norma ini dibedakan menjadi dua yaitu norma sosial dan norma sosiomatematika. Norma sosial merupakan pola umum interaksi sosial yang tidak terkait dengan materi pembelajaran sedangkan norma sosiomatematika merupakan pola interaksi dalam memahami konsep matematika.

Berdasarkan hal ini, norma sosiomatematika sangat penting dalam pembelajaran matematika namun pada kenyataannya masih terdapat beberapa orang yang meyakini bahwa pembelajaran matematika hanyalah sebuah proses individu dan interaksi sosial tidak berperan penting. Hal senada dengan Sulfikawati bahwa keterampilan dipandang penting karena ada hubungan yang cukup erat antara keterampilan sosial siswa dengan berbagai kemampuan lainnya seperti menjalin kerjasama dalam kelompok, berinteraksi dengan sebayanya, bergabung dalam kelompok, menjalin pertemanan baru, menangani konflik, dan belajar bekerja sama.(Sulfikawati, Suharto, \& Kurniati, 2016)

Hal ini senada juga dengan penelitian Sulfikawati yang menyatakan bahwa norma sosiomatematik dalam pembelajaran kolaboratif pokok bahasan segitiga dan segiempat di kelas VII-C SMP Negeri 11 Jember menunjukkan bahwa terdapat 27 dari 38 subyek penelitian memiliki kategori keyakinan positif (P1, P2, maupun P3) terhadap aktivitas kolaborasi dan memiliki rata-rata persentase norma sosiomatematik diatas $50 \%$ atau dengan kata lain subyek tersebut memiliki kemampuan komunikasi matematik dan keterampilan sosial dalam kategori baik bahkan sangat baik (Sulfikawati, Suharto, \& Kurniati, 2016). Komunikasi dalam hal ini adalah komunikasi matematis antara peserta didik dengan peserta didik dan antara peserta didik dengan guru. Melalui kegiatan komunikasi, peserta didik dapat bertukar ide dan pendapat, mengklarifikasi pemahaman dan pengetahuan yang mereka peroleh, dan lain sebagainya. (Rizkianto, 2013).

Menurut penelitian Widodo, pembelajaran Team Accelerated Instruction, norma sosiomatematik peserta didik program studi pendidikan matematika yang menempuh metode numerik dapat meningkat. Hal ini dapat dilihat dari perhitungan perbedaan pretes dengan post-tes sebesar 8,526 dan uji t (paired-samples T Test) sebesar 14,00 dengan taraf signifikansi 0,000 (Widodo \& Purnami, 2018). Selain itu dalam penelitian yang dilakukan oleh Kadir dengan judul mengembangkan norma sosiomatematik (sociomathematical norms) dengan memanfaatkan potensi lokal dalam pembelajaran matematika. Menurut Kadir, materi bahan ajar dan masalah yang dijadikan acuan dalam mengupayakan aktivitas belajar disusun dengan memanfaatkan potensi lokal sehingga siswa merasakan manfaat matematika dalam hidupnya, norma sosiomatematik dapat dikembangkan dengan menggunakan beberapa pendekatan pembelajaran, seperti pendekatan pembelajaran kontekstual, pembelajaran berbasis masalah, pendekatan matematika realistik, dan model pembelajaran kooperatif (Kadir, 2008).

Norma sosiomatematik ini sangat terkait dengan potensi lokal atau kearifan lokal. Pendidikan berbasis kearifan lokal merupakan pendidikan yang mengajarkan peserta didik untuk selalu dekat dengan situasi konkrit yang mereka hadapi dalam kehidupan sehari-hari. Menurut (Abdullah, 2008), 
kearifan lokal mengacu pada berbagai kekayaan budaya yang tumbuh dan berkembang dalam sebuah masyarakat yang dikenal, dipercayai, dan diakui sebagai elemen-elemen penting yang mampu mempertebal kohesi sosial di tengah masyarakat. Menurut (Sunandar, 2018) menyatakan bahwa sumber-sumber kearifan lokal terdiri dari potensi manusia, agama, budaya, dan alam. Setiap potensi akan diuraikan sebagai berikut di bawah ini. 1) Potensi Manusia Al-Ghazali menyebut potensi manusia ada empat komponen, yaitu: ruh, kalbu, akal dan nafsu. 2) Potensi Agama Hampir tidak ada pendidikan diberbagai belahan dunia ini yang lepas dari pengaruh agama, baik itu pendidikan formal maupun pendidikan non-formal 3) Potensi Budaya Budaya adalah nilai, proses dan hasil dari cipta, rasa dan karsa manusia. Model pendidikan berbasis kearifan lokal merupakan sebuah contoh pendidikan yang mempunyai relevansi tinggi bagi kecakapan pengembangan hidup dan berpijak pada potensi lokal setiap daerah.

Berdasarkan hasil wawancara dengan salah seorang guru SDN 224 Palae (Astuti, 2019) mengemukakan bahwa siswa sering melakukan diskusi dan berdebat dalam menyelesaikan masalah matematika jika jawaban mereka berbeda dengan temannya, terkadang tidak ada yang mau mengalah dan terkadang terjadi konflik antara satu dengan yang lain. Berdasarkan uraian tersebut, maka peneliti berinisiatif untuk melakukan analisis terkait interaksi antara siswa dengan guru maupun antarsiswa yang sesuai dengan kearifan lokal dalam pembelajaran matematika.

Berdasarkan uraian latar belakang di atas, penulis termotivasi untuk mengadakan sebuah penelitian dengan judul "Analisis Sosiomatematika Berbasis Kearifan Lokal dalam Pembelajaran pada Siswa SDN 224 Palae”.

\section{Metode}

Jenis penelitian yang digunakan adalah metode penelitian kualitatif dengan pendekatan eksploratif. Penelitian ini dilakukan untuk menggali informasi tentang pembelajaran sosiomatematika siswa pada SDN 224 Palae kelas V. Subjek dalam penelitian ini adalah siswa SD N 224 Palae kelas $\mathrm{V}$. Instrumen penelitian ini adalah peneliti sendiri dengan menggunakan teknik pengumpulan data yaitu perangkat pembelajaran, lembar observasi, wawancara dan dokumentasi. Peneliti menggunakan triangulasi teknik yaitu memadukan teknik observasi, wawancara dan dokumentasi. Observasi merupakan pengamatan langsung oleh peneliti terhadap segala aktivitas subjek penelitian. Observasi dalam penelitian ini dilakukan untuk mengetahui sosiomatematika berbasis kearifan lokal dalam pembelajaran matematika pada siswa SDN 224 Palae.

Dokumentasi merupakan dokumen berupa catatan, buku, foto, rekaman suara atau video yang terkait dengan penelitian. Dokumentasi dalam penelitian ini berupa foto aktifitas siswa terkait dengan sosiomatematika. Teknik ini digunakan untuk memperoleh data tentang aktivitas sosiomatematika siswa dalam pembelajaran matematika.

Wawancara atau interview merupakan tanya jawan antara peneliti dan subjek penelitian terkait dengan aktivitas siswa dalam pembelajaran matematika. Analisis data kualitatif penelitian ini mengacu pada Miles dan Huberman dalam Sugiyono, yaitu reduksi data, penyajian data, dan kesimpulan/verifikasi (Moleong, 2006)

Mereduksi data yaitu merangkum, memilih hal-hal pokok, memfokuskan pada hal-hal yang penting, mencari tema dan polanya serta membuang yang tidak perlu. Proses reduksi data dalam penelitian ini dilakukan dengan cara merangkum hasil observasi, wawancara dan dokumentasi yang masih bersifat acak ke dalam bentuk yang mudah dipahami. Hasil wawancara kata-kata yang tidak sesuai dengan tujuan penelitian akan dihilangkan.

Penyajian data dilakukan dalam bentuk phie chard atau sejenisnya. Melalui penyajian data, maka data terorganisasikan, tersusun dalam pola hubungan sehingga memungkinkan untuk menarik kesimpulan. Penyajian data dilakukan dalam bentuk uraian deskriptif sesuai dengan aspek yang diamati pada subjek penelitian sehingga lebih mudah dipahami.

Penarikan kesimpulan penelitian dari data yang sudah dikumpulkan dan memverikasikan dilakukan sesuai masalah yang diangkat dalam penelitian yaitu analisis sosiomatematika 


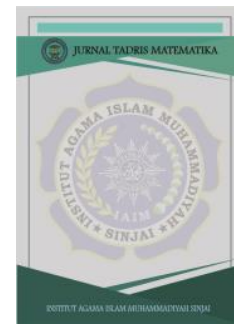

JTMT

Jurnal Tadris Matematika

Vol 1 No 22020

ISSN (print) : 2745-956X

ISSN (online) : 2745-9551

Homepage : http://journal.iaimsinjai.ac.id/index.php/Jtm

Dalam penelitian ini diperlukan alur penelitian untuk mempermudah proses penelitian seperti pada Gambar 1. Berdasarkan bagan pada gambar 1 dapat dijelaskan langkah-langkah penelitian yaitu: 1) Pendahuluan, pada langkah ini terdiri dari menentukan sekolah, kelas dan materi, 2) Membuat perangkat pembelajaran, pedoman observasi dan pedoman wawancara, pedoman observasi dan pedoman wawancara yang dibuat hanya merupakan garis besar pertanyaan tentang apa saja yang ingin diketahui peneliti. Pedoman observasi dan pedoman wawancara yang dibuat 3) Pelaksanaan, tahap ini terdiri dari pengumpulan data melalui observasi, dan wawancara siswa tentang aktivitas siswa dalam pembelajaran, 4) Verifikasi data, memverifikasi hasil pengumpulan data secara langsung terhadap penelitian, baik verifikasi hasil observasi maupun wawancara, 5) Analisis data, menganalisis hasil observasi maupun hasil wawancara mengenai aktivitas membilang yang dilakukan oleh siswa sekolah dasar, 6) Membuat kesimpulan, dari analisis data yang didapat mengenai bentuk aktivitas membilang yang dilakukan oleh siswa sekolah dasar, 7) Penyimpulan data, Pada tahap ini dilakukan penarikan kesimpulan terhadap hasil analisis data yang telah dilakukan pada tahap sebelumnya.

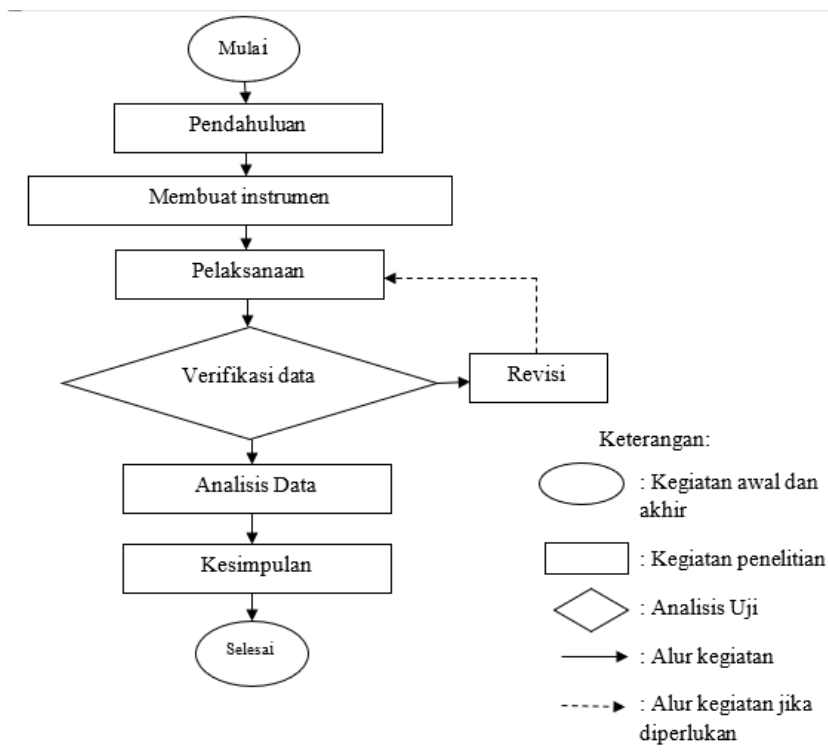

Gambar 1: Bagan Pengumpulan Data

\section{Hasil dan Pembahasan}

Penelitian ini dilakukan di SDN 224 Palae pada semester genap tahun pelajaran 2019/2020, subjek dalam penelitian ini adalah siswa kelas V dengan jumlah 20 siswa. Data hasil penelitian diawali dengan melakukan wawancara terhadap guru mata pelajaran matematika untuk mengetahui kemampuan matematika yang dimiliki oleh siswa dan mengetahui norma sosiomatematik yang terdapat di dalam kelas. Penulis dalam wawancara ini menanyakan norma sosiomatematika siswa dan kemampuan belajar matematika yang dimiliki siswa dalam pembelajaran di sekolah. Adapun indikator sosiomatematika yang digunakan dalam penelitian ini yaitu prosedur pemecahan masalah, rosedur pemecahan masalah yang dapat diterima, alternatif prosedur, dan perumusan prosedur yang lebih efektif.

\subsection{Pembelajaran Konvensional}

Berdasarkan dokumen hasil kerja siswa dalam pembelajaran konvensional, bentuk sosiomatematika yang dapat diamati yaitu: 


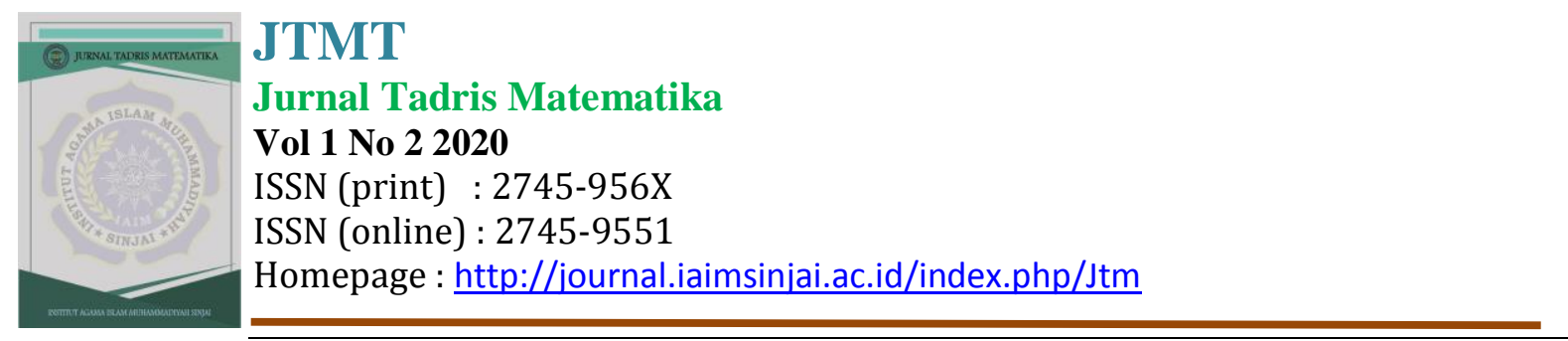

a. Prosedur Pemecahan Masalah

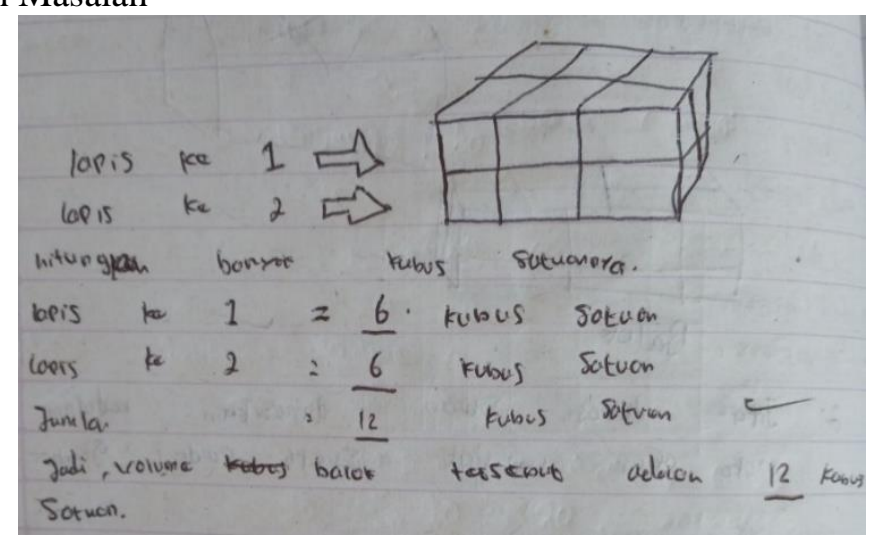

Gambar 2. Hasil Kerja siswa

Berdasarkan hasil kerja siswa di atas terlihat bahwa siswa mampu menyelesaikan lembar kerja sesuai prosedur yang diberikan. Hal ini dapat dilihat juga dari hasil kerja siswa berikut ini

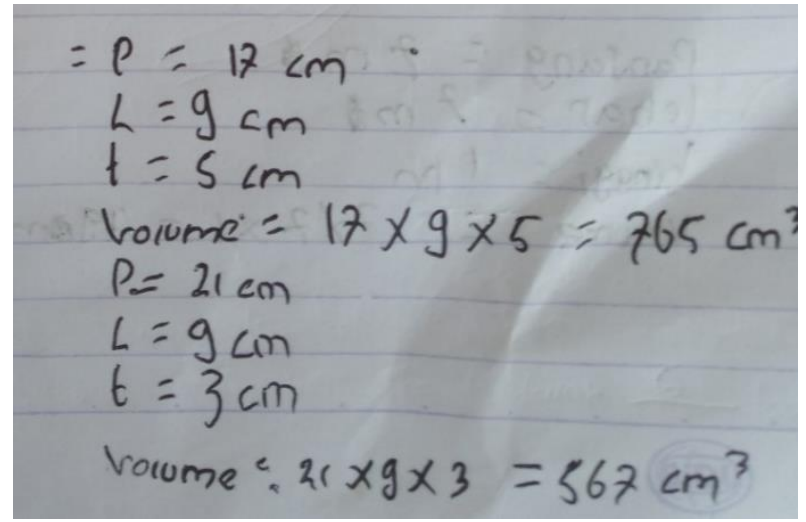

Gambar 3 Hasil kerja siswa sesuai prosedur

Hal ini menunjukkan bahwa siswa hanya menyelesaikan sesuai prosedur atau sesuai dengan rumus yang telah diberikan.

\subsection{Pembelajaran Realistik Matematic Education}

Berdasarkan dokumen hasil kerja siswa dalam pembelajaran Realistik Matematic Education, bentuk sosiomatematika yang dapat diamati yaitu:

a. Prosedur Pemecahan Masalah

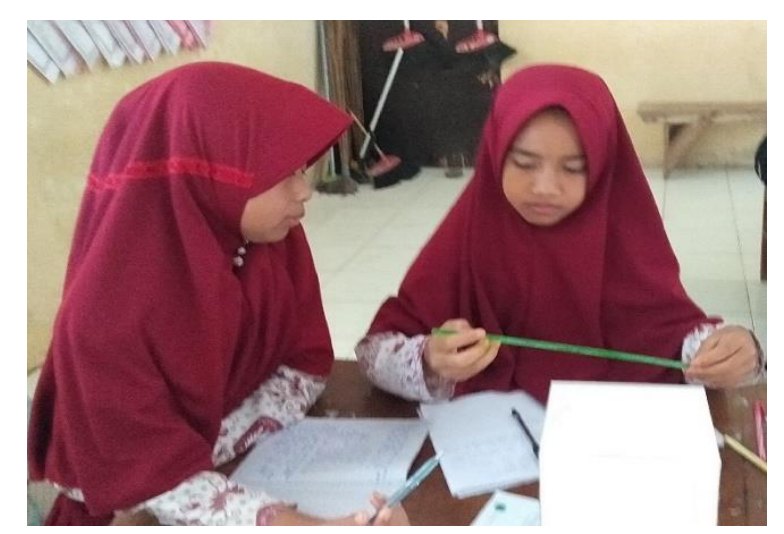

Gambar 4. Mengukur Alat peraga berbentuk Balok 


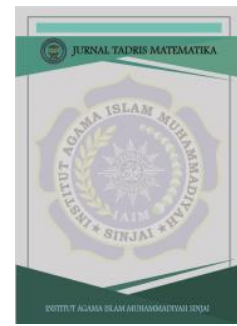

\section{JTMT}

Jurnal Tadris Matematika

Vol 1 No 22020

ISSN (print) : 2745-956X

ISSN (online) : 2745-9551

Homepage : http://journal.iaimsinjai.ac.id/index.php/Jtm

Beradsarkan hasil observasi, siswa dapat mengukur terlebih dahulu panjang, lebar, dan tinggi sebuah alat peraga balok sebelum menentukan volumenya.

b. Alternatif Prosedur

Berdasarkan hasil observasi, siswa dapat menghitung volume keseluruhan beberapa alat peraga berbentuk balok dan kubus yang memiliki ukuran sama dengan cara hanya menghitung satu volume benda kemudian mengalikan dengan banyaknya benda. Berdasarkan wawancara, siswa menyatakan bahwa volume 5 buah kubus sama dengan 5 kali volume satu kubus.

\subsection{Pembelajaran Konstekstual}

Berdasarkan dokumen hasil kerja siswa dalam pembelajaran konstekstual, bentuk sosiomatematika yang dapat diamati yaitu:

a. Alternatif Prosedur

Berdasarkan observasi dan wawancara, siswa mengukur sebuah bangunan berbentuk balok dengan menggunakan mistar. Siswa menyelesaikan masalah dengan cara pengukuran bersambung. Siswa mengukur sampai batas mistar kemudian melanjutkan pengukuran pada jarak berikutnya. Hasil pengukuran didapatkan dengan menjumlahkan jarak sebelumnya dengan jarak berikutnya.

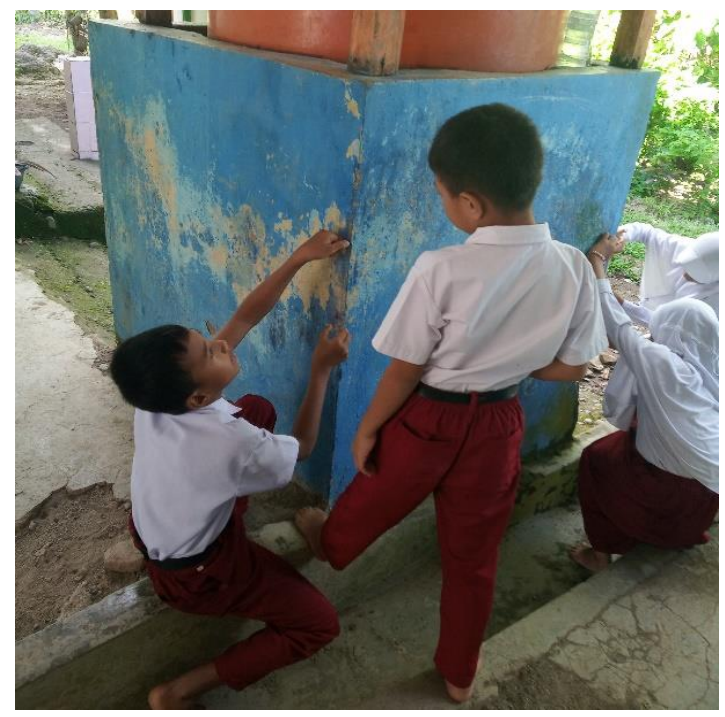

Gambar 5 Mengukur Bangunan dengan Mistar

b. Perumusan prosedur yang lebih efektif

Berdasarkan observasi dan wawancara, siswa mengukur sebuah bangunan berbentuk balok dengan menggunakan mistar. Siswa menyelesaikan masalah dengan cara pengukuran bersambung. Siswa mengukur sampai batas mistar kemudian melanjutkan pengukuran pada jarak berikutnya. Hasil pengukuran didapatkan dengan mengalikan panjang mistar dengan banyaknya perpindahan.

c. Prosedur pemecahan masalah yang dapat diterima

Berdasarkan hasil observasi, siswa tidak mendapatkan benda di sekita yang berbentuk kubus sehingga siswa berinisiatif untuk membentuk sebuah balok dari buku mereka. Selain itu, ada juga siswa yang berinisiatif menumpuk batu bata menjadi sebuh bentuk kubus. Hal ini merupakan sebuah pemecahan masalah yang dapat diterima. 


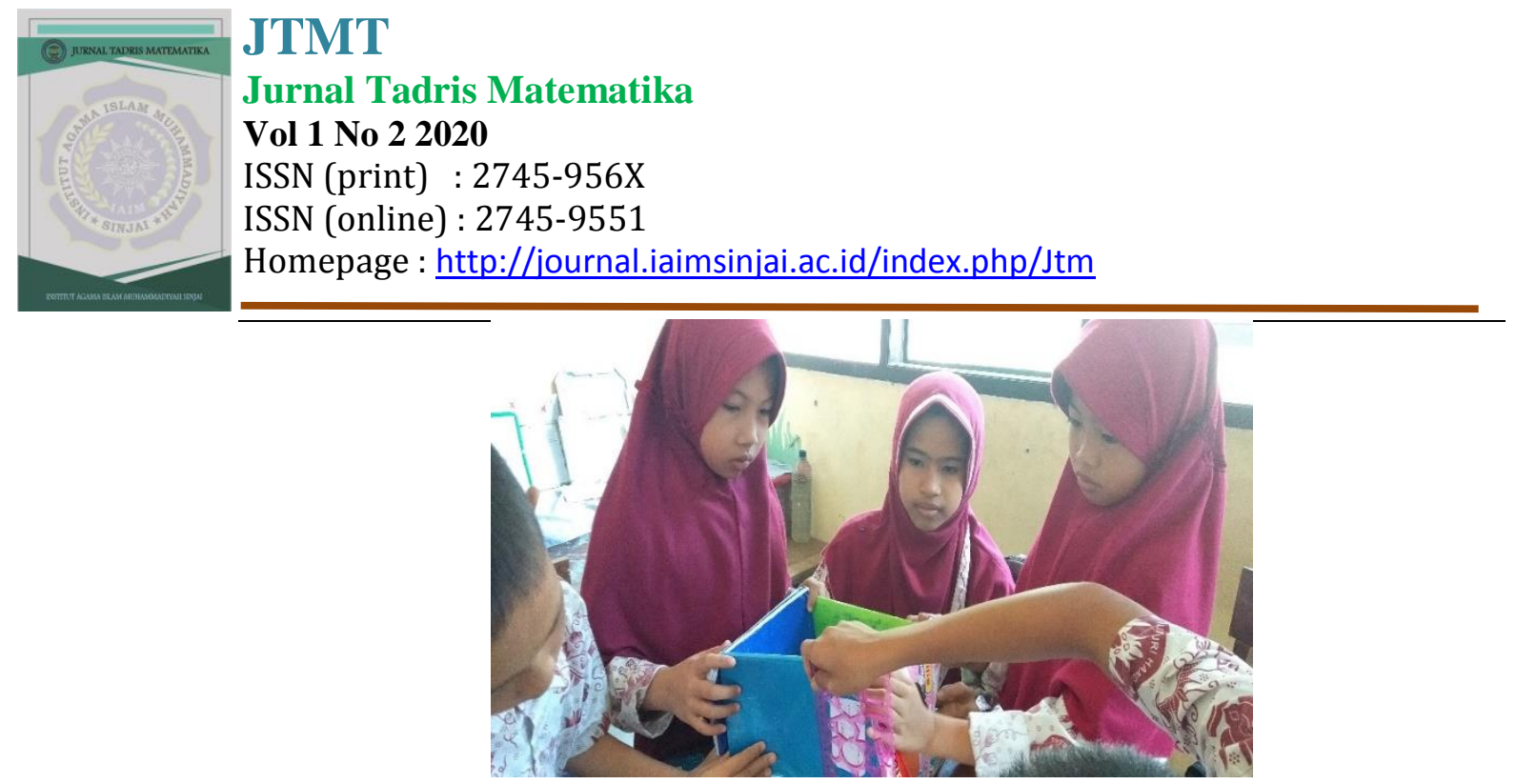

Gambar 6 Membentuk Buku menjadi bentuk Kubus

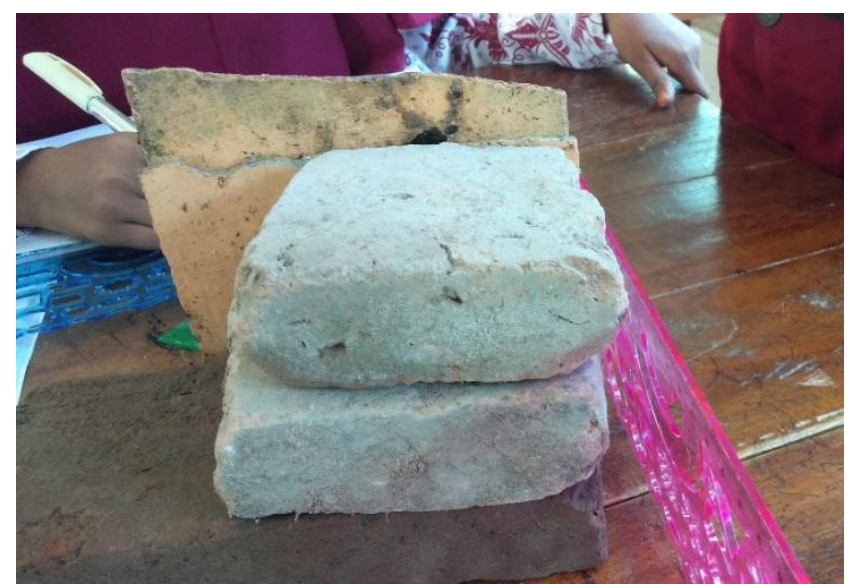

Gambar 7 Membentuk Batu bata menjadi Bentuk kubus

Berdasarkan penjelasan di atas dapat dibandingkan bahwa ketiga pemebalajaran tersebut yaitu pembelajaran konvensional, pembelajaran matematika realistik, dan pembelajaran kontekstual masing-masing memiliki kelebihan dan kekurangan. Pembelajaran ini dapat digunakan sesuai dengan materi yang diajarkan serta disuesuaikan dengan kondisi (kemampuan siswa). Berdasarkan hasil penelitian bahwa pembelajaran kontekstual merupakan pembelajaran yang dapat diterapkan dalam mengasah kemampuan sosiomatematika siswa SDN 224 Palae Kelas V yang berbasis pada kearifan local. Hal ini dikarenakan pada pembelajaran kontekstual siswa dituntut untuk mengaitkan antara materi yang diajarkannya dengan situasi dunia nyata siswa dan mendorong siswa membuat hubungan antara pengetahuan yang dimilikinya dengan penerapannya dalam kehidupan mereka sehari-hari, dengan melibatkan tujuh komponen utama pembelajaran kontekstual, yakni: kontruktivisme, bertanya, inkuiri, masyarakat belajar, pemodelan dan penilaian autentik. Dapat dilihat ketika siswa mengerjakan soal yang diberikan, siswa menggunakan seluruh benda dan alat yang sesuai dengan materi pembelajaran untuk dijadikan sebagai benda yang dapat diukur. Ada yang menggunakan batu, bak air, buku yang disusun, pintu, lemari, dan benda yang berhubungan dengan materi.

\section{Simpulan}

Simpulan dari hasil penelitian ini adalah pembelajaran matematika yang dilakukan di kelas dapat mengasah siswa untuk melakukan interaksi baik kepada temannya atau guru. Interaksi siswa tergantung dari strategi, model pembelajaran atau pendekatan yang digunakan oleh guru. Dalam penelitian ini digunakan pendekatan konvensional, matematika realistik dan konstekstual untuk mengkaji secara mendalam tentang sosiomatematika yang terjadi dalam pembelajaran matematika 


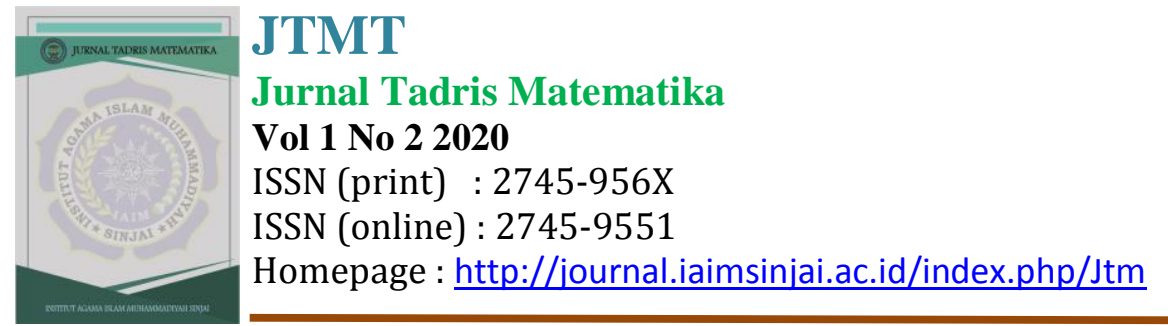

kelas V SDN 224 Palae. Berdasarkan hasil penelitian, pembelajaran matematika realistik dan pembelajaran kontekstual dapat mengasah kemampuan sosiomatematika siswa SDN 224 Palae Kelas $\mathrm{V}$ yang berbasis pada kearifan lokal. Adapun indikator sosiomatematika yang dapat dicapai oleh siswa dengan pembelajaran matematika realistik adalah prosedur pemecahan masalah, alternatif prosedur sedangkan pada pembelajaran kontekstual adalah alternatif prosedur, perumusan prosedur yang lebih efektif, dan prosedur pemecahan masalah yang dapat diterima.

\section{Daftar Pustaka}

Abdullah, I. (2008). Agama dan Kearifan Lokal dalm tantangan Global. Yogyakarta: Pustaka Pelajar.

Astuti, S. (2019, November 12). Interaksi dalam Pembelajaran. (Irmayanti, Pewawancara)

Kadir. (2008). mengembangkan norma sosiomatematik (sociomathematical norms) dengan memanfaatkan potensi lokal dalam pembelajaran matematika. Phythagoras, 4(1), 74-85.

Moleong, L. (2006). Metodologi Penelitian Kualitatif. Bandung: Remaja Rosda Karya.

Rizkianto, I. (2013). Norma Sosiomatematika dalam Kelas Matematika. Seminar Nasonal Matematika dan Pendidikan Matematika (hal. 42). Yogyakarta: FMIPA UNY.

Sulfikawati, D., Suharto, \& Kurniati, D. (2016). Analisis Norma Sosiomatematik dalam Pembelajaran Kolaboratif Pokok Bahasan Segitiga dan Segiempat di Kelas VII-C SMP Negeri 11 Jember (Sociomathematical Norms Analysis in Collaborative Learning in Triangle and Quadrilateral Topic at VII-C of Junior High S. Edukasi Unej, 1-4.

Sunandar. (2018). Pembelajaran Matematika Berbasis Kearifan Lokal. Prosiding SNPMAT. Jawa Tengah: Studi Pendidikan Matematika Universitas PGRI Semarang.

Widodo, S. A., \& Purnami, A. S. (2018). Mengembangkan Norma sosiomatematika dengan Team Accerated Instruction. Matematika dan Pendidikan Matematika, 29-48.

Wijaya, A. (2012). Pendidikan Matematika Realistik. Yogyakarta: Graha Ilmu. 